
the Creative Commons Attribution licence (https://creativecommons.org/licenses/by/4.o/), which permits unrestricted re-use, distribution, and reproduction in any medium, provided the original work is properly cited. doi:IO.IOI7/So003581521000330 First published online or December 202 I

\title{
AVERHAM, ST MICHAEL, NOTTINGHAMSHIRE: A NEWLY IDENTIFIED PRE-CONQUEST CHURCH
}

\author{
Christopher J Brooke, FSA 10 and Peter F Ryder, FSA \\ Christopher Brooke, Department of History, University of Nottingham, Nottingham \\ NG7 2RD, UK. Email: chris.brooke@nottingham.ac.uk \\ Peter Ryder, The Vicarage, Otterburn, Northumberland NE19 1NP, UK. Email: pfryder@, \\ broomlee.org \\ The church of St Michael and All Angels, Averham, is largely constructed of counter-pitched rubble \\ and has long been interpreted as being of the early Norman period. Recent archaeological inves- \\ tigations by the authors have revealed conclusive evidence that the date of part of the fabric is \\ pre-Conquest and that the west tower was originally a possible two-storey porch. Ground-based \\ remote sensing has further revealed complex anomalies in the south and east walls of the tower.
}

Keywords: Anglo-Saxon; medieval; church architecture; dendrochronology; remote sensing; structural analysis

\section{INTRODUCTION}

The church of St Michael and All Angels, Averham, is positioned on the edge of the west bank of the River Trent $3 \mathrm{~km}$ west of Newark upon Trent in east-central Nottinghamshire at national grid reference SK 767544 . The church is isolated from the village and lies at the end of a track at its extreme eastern end at a height of $12.5 \mathrm{~m}$ above sea level (figs I and 2). The earthworks of a medieval moated site exist $300 \mathrm{~m}$ due west of the church.

The origin of the Averham place-name appears to lie in the Old English egor, in the dative plural form e grum, ${ }^{\mathrm{I}}$ and probably means the 'place of the floods', which makes perfect sense given the location of the village by the River Trent. The earliest known reference to the settlement is in Domesday Book where it is recorded as Aigrun formerly in the land of Swein and now (IO86) Gilbert Tison; a church and a priest are recorded. ${ }^{2}$ Swein of Averham occurs in four other contexts, all in Nottinghamshire, holding land at nearby Staythorpe, Winkburn, Cromwell and further afield at Finningley, but Averham had the highest value at $£ 6$, with Winkburn coming next at $£ 5 .{ }^{3}$ The valuation in 1086 was fIO I2s, indicating a relatively prosperous village, having far greater value than its surrounding neighbours, and even the large, nearby town of Newark was worth only $£ 34$ in comparison.

I. Mills 20 II.

2. Morris and Parker 1977; Williams 2003.

3. PASE Domesday http://domesday.pase.ac.uk/ (accessed 2I Oct 202I). 


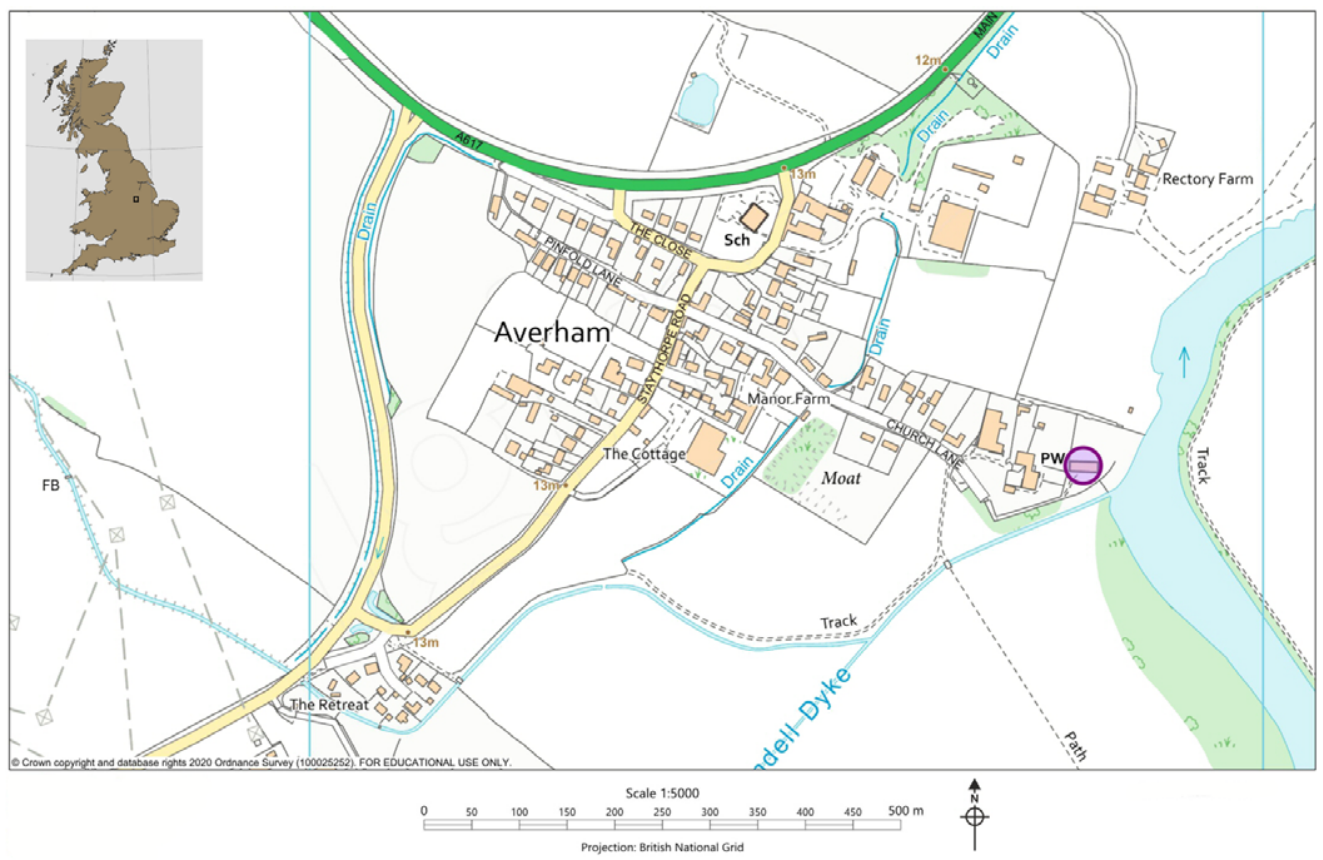

Fig I. Location map of Averham St Michael. Map: authors.

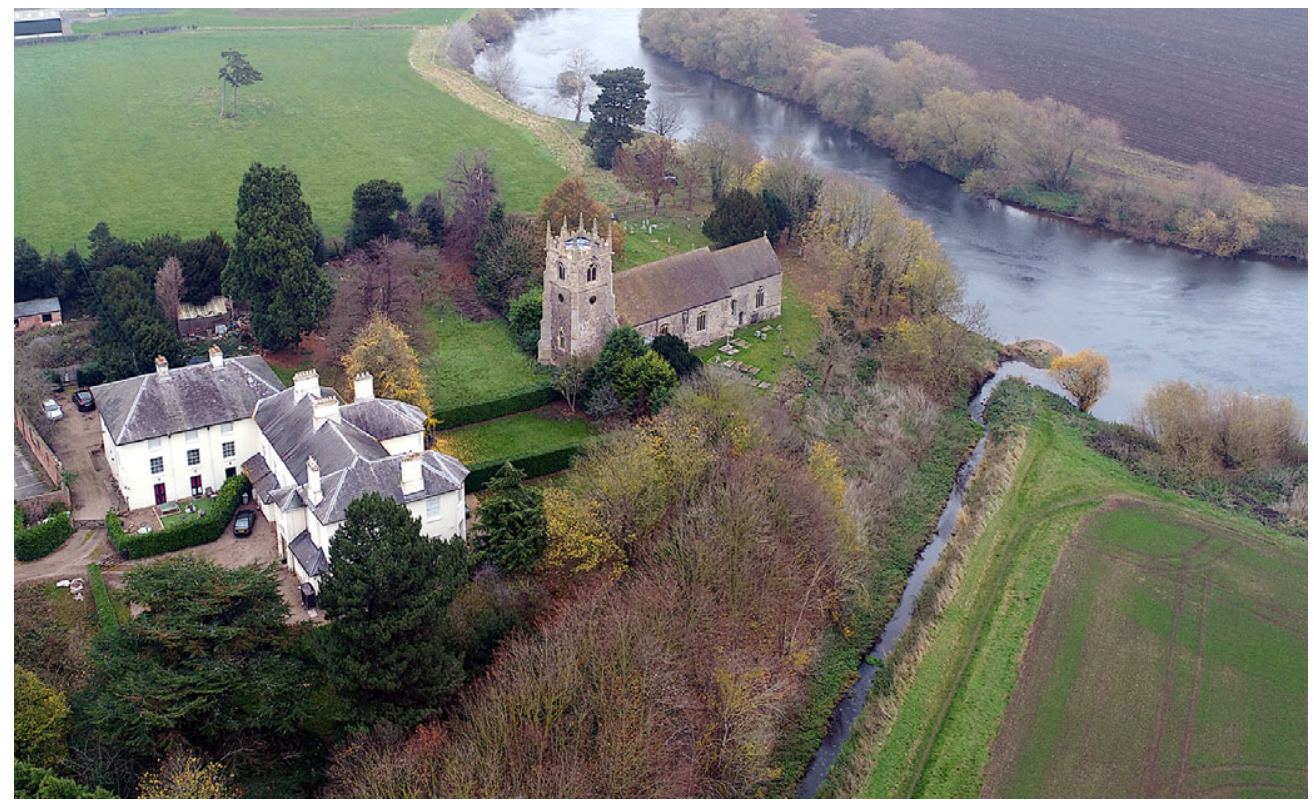

Fig 2. Aerial photograph of Averham St Michael from the south-west showing its isolated position on the west bank of the River Trent. Photograph: Richard Carlton. 
Apart from the reference to a church in the Domesday survey, the next earliest record is found $c$ I IOO when Gilbert Tyson made a gift in free alms (that is, free of secular services) of tithes in Averham (Aigruna) to Selby Abbey. ${ }^{4}$ Selby is recorded in the Valor Ecclesiasticus as receiving $£ 2$ annually as a temporal fee from the Rector of Averham. ${ }^{5}$ However, in July I227 Archbishop Walter Gray instituted Richard Markham, clerk, to the church on the presentation of the brethren of St John of Jerusalem. ${ }^{6}$ A preceptory of the Knights Hospitaller is known to have been established during the twelfth century at Ossington, I0.5 km to the north, ${ }^{7}$ and they held other local churches, notably Winkburn, ${ }^{8}$ and so clearly also held the advowson of Averham at this time.

The village and church remained comparatively wealthy throughout the medieval period. The manor was granted to the Lexington family by Robert le Sauvage in payment for a debit, Henry de Lexington was Dean (1245-53) then Bishop (I253-8) of Lincoln, but the manor passed to the Sutton family by marriage after $1250 .{ }^{9}$ At the I29I Taxatio of Pope Nicholas IV, St Michael's church had a clear annual valuation of $£ 20$ and was recorded as being in the secular patronage of Agnes, widow of Sir James de Sutton, knight. ${ }^{\text {Io }}$ Patronage continued under the influential Sutton family until the middle of the nineteenth century. ${ }^{\text {II }}$

The church was evidently never large, currently comprising an aisleless nave with south porch, chancel with north vestry-mausoleum and a west tower. There is no evidence that the nave or chancel ever had aisles or chapels, the side walls are almost exclusively constructed of counter-pitched rubble with windows inserted in the thirteenth, fourteenth and fifteenth centuries. The present south porch was added $c$ I 500 by the Sutton family, as it carries their arms on the outer entrance and is clearly of late Perpendicular style; also of this date is the tower parapet, which is crenellated, has shields in panels and eight late Perpendicular-style crocketed pinnacles. Four diagonal buttresses to the tower are contemporary with the porch and parapet. The east wall of the chancel appears to be an addition or rebuilding of the early fourteenth century. The mausoleum for the Sutton family was added onto the north side of the chancel apparently in the late eighteenth century, though it has no architectural features by which to date it other than an inserted nineteenth-century window on the north side; thermal remote sensing has revealed a possible window and other archaeological anomalies below the external render. ${ }^{\text {I2 }}$

In 1980 the lead author had noted the presence of a blocked doorway at first-floor level in the west tower and what appeared to be a pitched roofline above; however, the constraints of access to these features precluded further study at this time. In 2012 a project commenced to rehang and augment the bells, to replace the clock and to remove an intermediate nineteenth-century floor. The outcome was to give unprecedented access to the upper levels of the tower which formerly had been exceedingly restricted.

4. ERYA, DDGU/2/3I; Clay and Farrer 1965

5. Caley and Hunter $1825,187$.

6. Raine 1872,16 .

7. BL, Harleian Charter, 44 E $2 \mathrm{I}$.

8. PRS, I9I3, II5; Larking I857, II4-5.

9. Thoroton $1790-6$, III, IO8.

IO. Astle et al I802, 284; Brown and Thompson I940, 274.

II. NA, Acc 6474 PD 208/17; Mellors 1924, 317-I8.

I2. Brooke 2018. 


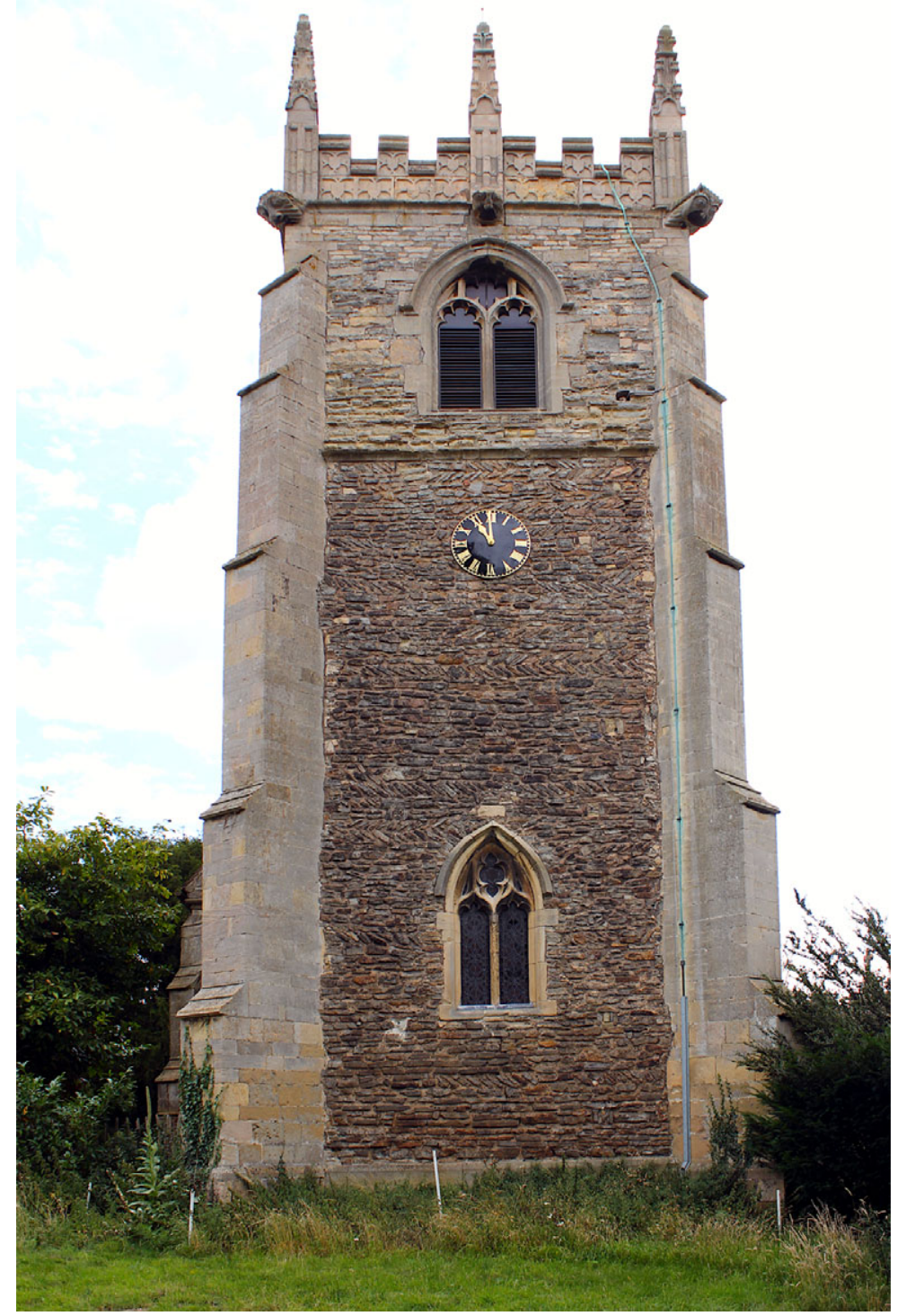

Fig 3. The west elevation of the tower showing the inserted lower window, counter-pitched rubble fabric and later medieval belfry and parapet. Photograph: authors.

THE EXTERIOR FABRIC

\section{West tower}

The west tower (fig 3 ) rises in one tall, unbroken stage to a casement-moulded string below the belfry; up to this level the walls are of coursed roughly-square stone with much interspersed counter-pitched coursing, and obvious putlog holes. In the west wall are three pairs of putlogs, with one towards each end of the wall, up to the level of the head of the west window, and three more above near the south end of the wall. This early fabric, comprising 
mainly Trent Valley mudstone (lias), has a distinctive brownish lime mortar with small, rounded, river-washed pebbles. There is a tall ashlar plinth of limestone, apparently secondary, and diagonal ashlar buttresses at the angles that obscure the tower quoins; the buttresses have chamfered plinths, moulded offsets and die into the walls just below the parapet.

The west window is of two trefoiled ogee-headed lights with a quatrefoil between, and has a steep two-centred arch with a hood chamfered above and below, in a double-chamfered surround; there is disturbed masonry around the jambs and head, suggesting that the window replaces an earlier opening. There is a clock dial about a metre below the string course. The belfry stage above is of coursed yellowish roughly-squared stone, quite badly eroded, up to around a metre above the sills of the openings; then there are larger squared blocks (which on the east can be seen to represent an earlier embattled parapet) up to the level of the heads of the openings, and above that more regularly-coursed whiter stone. The belfry openings are each of two cinquefoil-headed lights with pierced quatrefoils in the spandrel, within a double-chamfered surround, and under a casement-moulded hood with turned-back ends. The parapet has a moulded string at its base and crocketed pinnacles, each with two vertical sunk panels at their bases, and the crenellated parapet has two tiers of panels with plain shields. Photographs from the turn of the twentieth century show the upper part of the pinnacles in the centre of the east and west sides of the parapet as missing, and inspection reveals that these two pinnacles are of much newer stone, so in their present form these must be from a recent restoration.

The south elevation of the tower is of similar fabric to the west, except that it has a chamfered plinth at a lower level, which may be contemporary with the core fabric. As on the west there are counter-pitched courses and pairs of putlog holes, but there is what appears to be a column of rebuilt masonry, in bluer stone and without counter-pitching, at the east end of the wall above the nave eaves. There is a clock dial, as on the west, but with a disturbed patch of fabric below it, which may represent an earlier opening. At the point at which the south-east buttress meets the nave roof there is a horizontal division in the fabric that, although of similar character to that above, appears generally less-well constructed; within this lower area, towards the west side, are the remnants of a former lime render covering. Remote sensing imaging has revealed five distinct zones of different fabric type on this elevation. ${ }^{13}$

In order to study and highlight the phase differences of the south elevation, an image analysis technique, Random Forest (RF) classification, has been utilised on a rectified, visible light image. $\mathrm{RF}$ is a machine learning algorithm often used in remote sensing analysis and is widely regarded as a reliable predicator of specific features, based on a nonparametric method for modelling the continuous and discrete data of decision tree methods. ${ }^{\mathrm{I}} 4$ Pixels in the imagery are 'trained' using visually discrete zones in the fabric and the algorithm then calculates areas of similarity. Training in this case, using pixel classification for intensity, edge and texture, with the sigma of the Gaussian set between 0.3 and I5.0, has been rigorously controlled to those areas that have visually discrete structural properties in order to avoid over classification or incorrect group assignment. ${ }^{15}$ Fig 4 shows a

I3. Brooke I986.

I4. Breiman 200I; Belgiu and Drăguţ 20I6; Avand et al 20I9; Brooke and Clutterbuck 2019.

I5. Fornaser et al 2019; Konukoglu and Glocker 2020. 


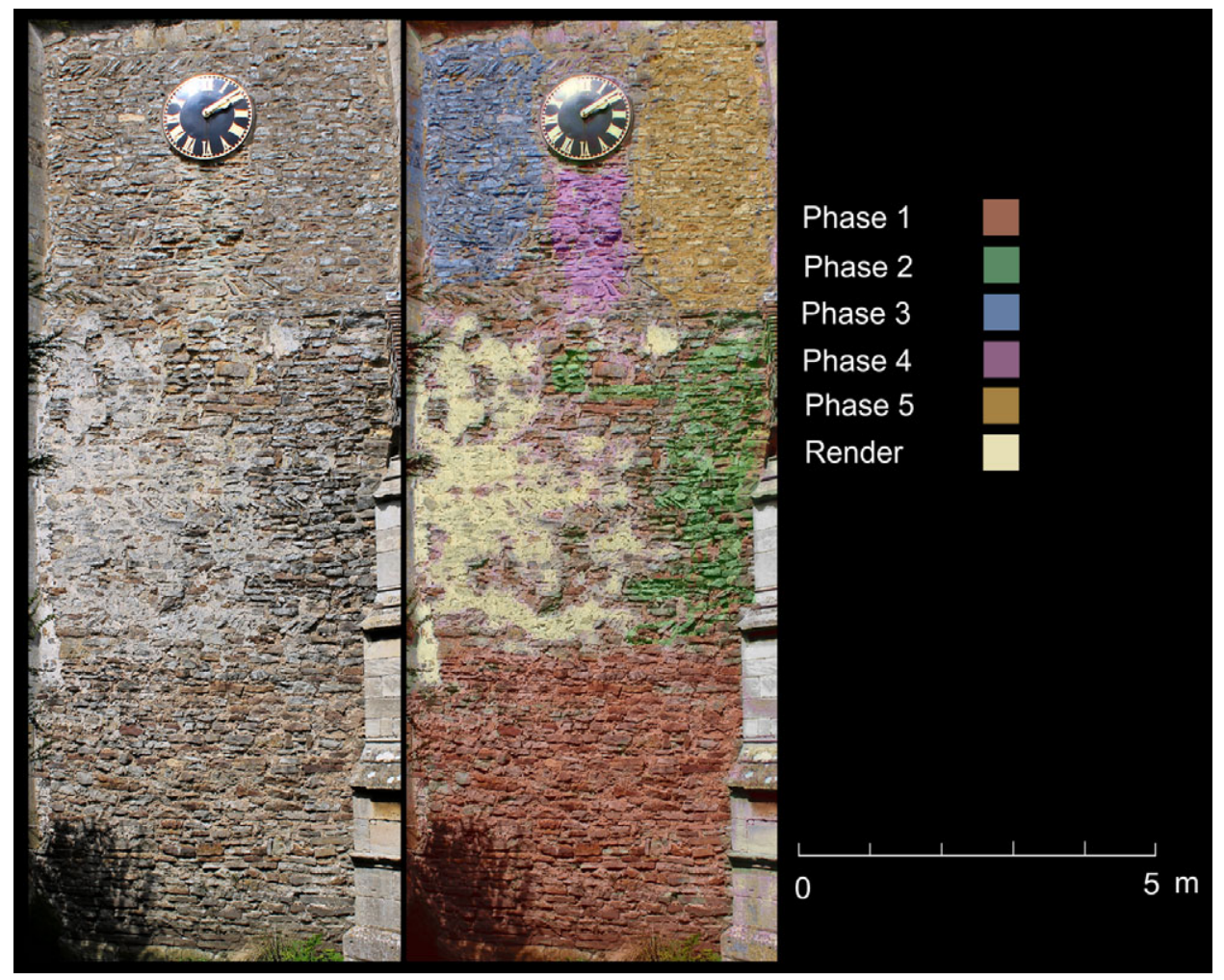

Fig 4. The south elevation of the tower with (right) Random Forest predication showing the different forms of building construction. Photograph: authors.

photograph of the south elevation alongside the RF classification. The five 'phases' illustrated are not necessarily in period order, although clearly Phase I precedes all other phases but interestingly appears to lie below the rendered area and among Phase 2; this implies that Phase 2 may have been a repair or partial rebuilding.

The north wall of the tower is again similar, with an original plinth as on the south, although here much of the fabric is concealed by render; to the east, the tower walling appears to butt up against similar fabric in the west wall of the nave.

On the east, above the nave roof, there is a clear contrast between the early fabric, with counter-pitched courses north of the nave ridge, and rebuilt walling without counterpitching on the south (fig 5). On this side, the earlier crenellated parapet, at the level of the springing of the heads of the present belfry openings, is very clear.

From the visual and remote sensing evidence, therefore, it is obvious that the belfry stage is a later replacement or addition to the tower, and the parapet, buttresses and gargoyles appear to date from the turn of the fifteenth century. The lower, earlier stage has at least five distinct phases on the south elevation and perhaps a single phase on the west, although disrupted by the later addition or alteration of a window opening and the addition of a clock dial. The north elevation is largely obscured by thick render, but the fabric appears to be of similar character to that on the west elevation. 


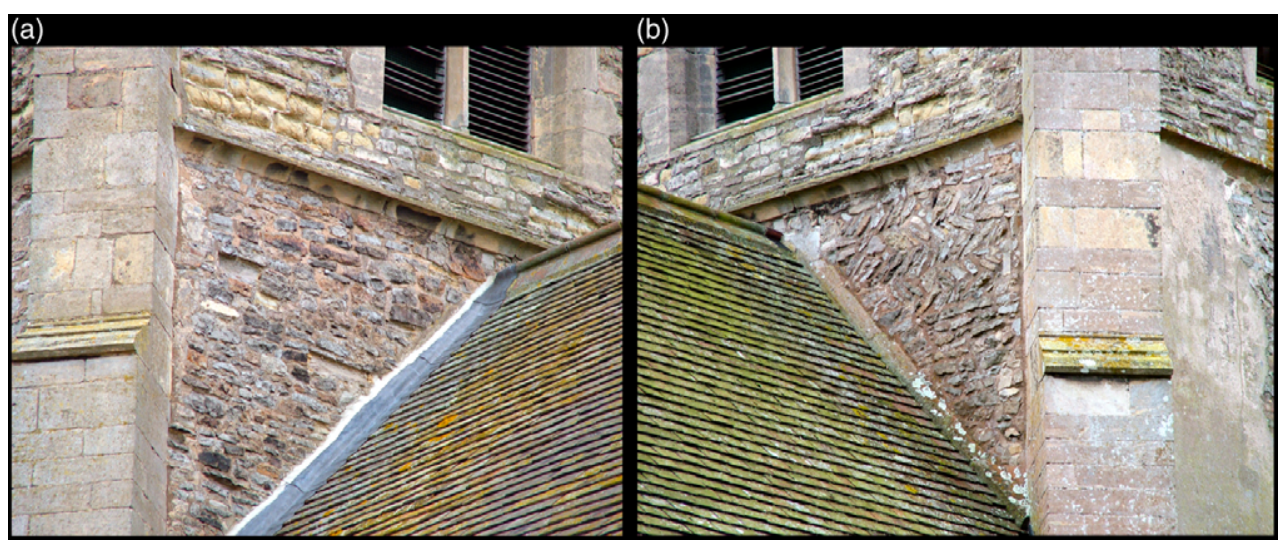

Fig 5. The east elevation of the tower below the belfry stage, (a) on the south side showing coursed rubble construction with no counter-pitching; (b) on the north side showing counter-pitched rubble consistent with the exposed areas of the north elevation and with internal construction. Photograph: authors.

\section{Nave and chancel}

The nave and the western part of the chancel retain much early fabric, which differs from that in the tower in being, where undisturbed, virtually entirely of counter-pitched stone laid in opposed or 'herringbone' courses, rather than the occasional counter-pitched course, or pair of courses, being interspersed with conventional horizontally-coursed rubble (fig 6). All this material comprises local Trent Valley mudstone. The original fabric is best preserved on the north of the nave; on the south there has been extensive patching, especially in the eastern bay and towards the wall heads, as there has been in the chancel, where the early fabric ends well short of the east end, which looks to have been extended by two or three metres. Ketton stone has been used along with Lincolnshire limestone in the patching. There is no sign of any original plinths.

Later buttresses of buff ashlar, very like those of the tower (except that they have a casement-moulded string $c \mathrm{I} .2 \mathrm{~m}$ above the ground), are set diagonally at the angles of the nave and articulate its side walls into three bays, although on the south there is a projecting porch rather than a buttress between the central and western bays. The buttresses die into the wall just below a casement-moulded eaves cornice, which is returned horizontally on the end walls flanking chancel and tower; the upper part of the buttress to the east of the porch has been rebuilt in 'tooled-and-margined' nineteenth-century ashlar. Each bay has a threelight window, probably contemporary with the buttresses but not placed symmetrically with them, in all likelihood because they replace earlier openings in the same positions. On the north of the nave (fig 7) the western bay contains a blocked north doorway, which has a low Tudor arch with continuous mouldings, its head formed by two diagonally-set blocks; to its west is a window of three trefoil-headed lights under a four-centred arch, with a broad chamfered surround and a casement-moulded hood with eroded head stops. The ground level towards the west end of the wall seems to have been lowered, as the northwest buttress has a rough squared footing now $c 0.30 \mathrm{~m}$ above the ground. 


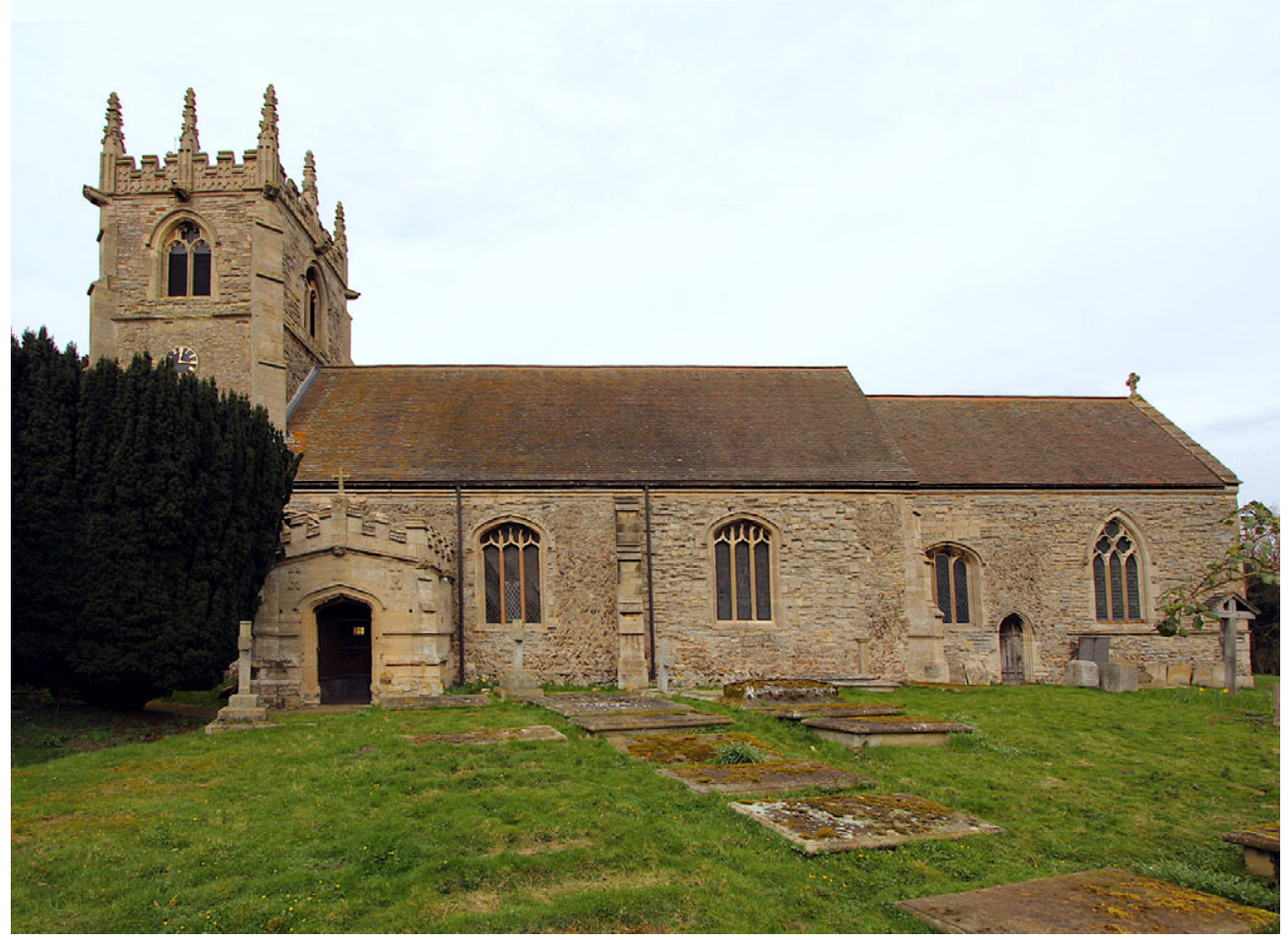

Fig 6. The church from the south showing the varied forms of rubble construction, inserted windows and the early sixteenth-century porch. Photograph: authors.

A tiny fragment of possibly decorated limestone is located above the blocked north doorway and is included in the Corpus of Anglo-Saxon Stone Sculpture. ${ }^{16}$ However, its identification as a scrap of reused, carved material is extremely dubious, as acknowledged by the authors of the corpus, and the authors of this paper could not identify any meaningful patterning.

The south wall of the chancel has two three-light windows with a priest's door between them. The western window has a four-centred arch enclosing uncusped lights, the central with a Tudor arch and the side with segmental-pointed arches, under a casement-moulded hood with turned-back ends. Below its sill is an area of coursed blue lias rubble, perhaps suggesting that it replaces an older window set lower in the wall, and above it is an area of ashlar blocks. The priest's door has a two-centred arch of two continuous hollow chamfers, and a chamfered hood with worn head stops; above the doorway older counter-pitched rubble rises to two-thirds the height of the wall. One metre to the east of the doorway a string course, $1.5 \mathrm{~m}$ above the ground, commences, chamfered above and hollow chamfered below. Eastward of this the early masonry only survives below the string and terminates beneath the eastern lights of the second window, beyond which the wall is of coursed roughly-squared blocks of blue lias stone, except for a course or two of larger squared blocks directly below the eaves cornice, which is chamfered on its lower angle. At the eastern angles of the chancel are fairly well-squared quoins, varying considerably in shape

I6. Everson and Stocker 2015, 93. 


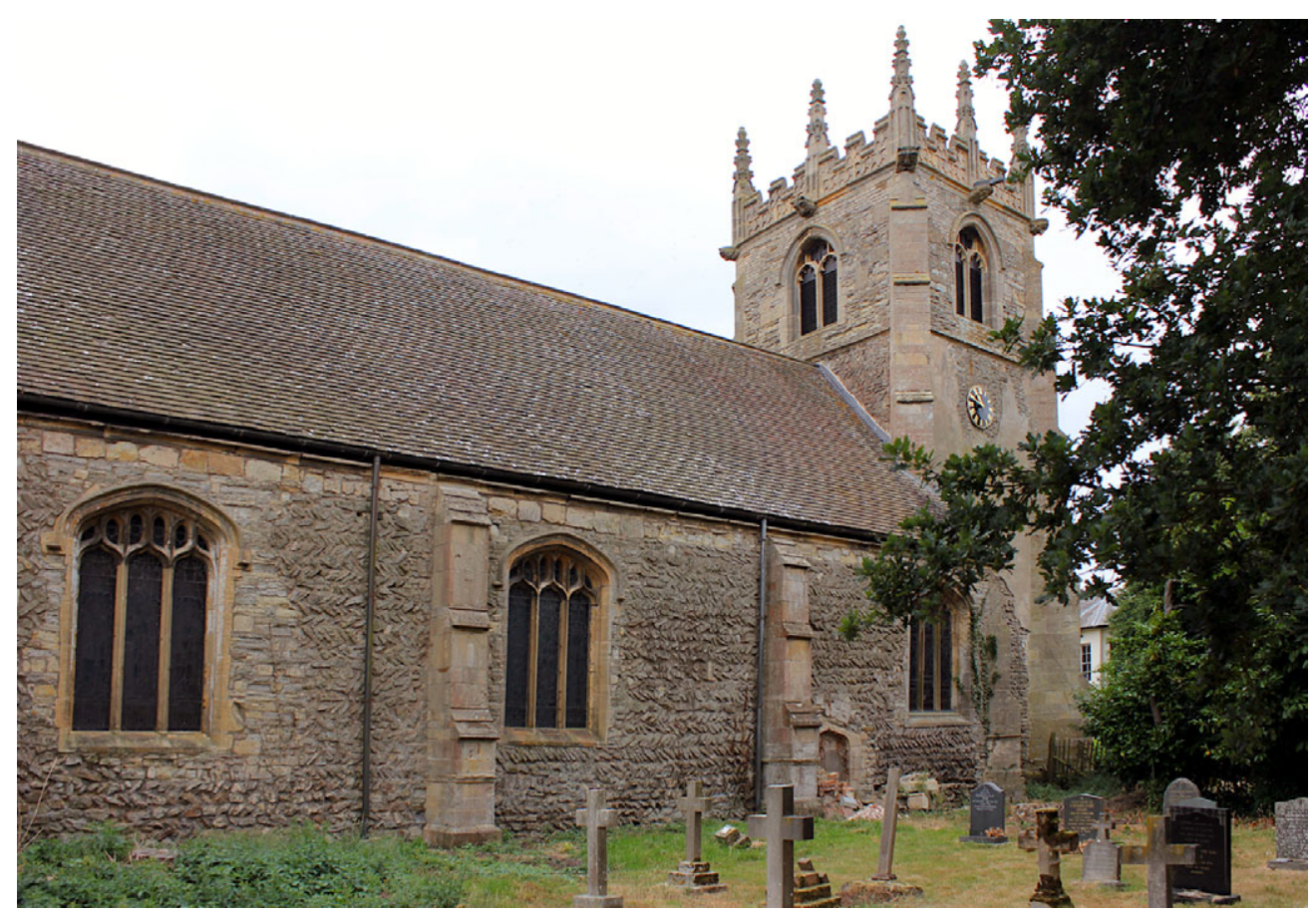

Fig 7. The church from the north-east illustrating the extensive counter-pitched rubble construction of the side walls and the small, blocked Tudor doorway in the western bay. Photograph: authors.

and size; some of the upper quoins are quite elongated blocks, unlike those below. The east end of the chancel is all of coursed lias stone, and the string course is continued across it below a large five-light window with intersecting tracery, typical of fourteenth-century form. The greater part of the north wall of the chancel is covered by the vestry; the short section of wall to the east has had the string course cut back flush with the wall face. To the west is a window of two trefoiled lancet lights with a quatrefoil above under a two-centred arch and a hollow-chamfered hood with head stops (the eastern damaged); stylistically, the window looks of earlier fourteenth-century date, although the tracery may have been restored.

\section{South porch}

The south porch is of the same buff ashlar limestone as the buttresses; it has a moulded plinth and a casement-moulded string $c \mathrm{I} .2 \mathrm{~m}$ above the ground, with another string (interrupted by a gargoyle midway along each side wall) below the embattled parapet. Between the diagonal buttresses at the outer angles is a Tudor-arched doorway and above is a pair of shields, with raised initials and devices relating to Sir Thomas Sutton (d. I525) and his wife, who remodelled the church. The entire structure has evidently been constructed in a single phase $c$ I500, effacing any evidence of earlier work at this location.

Inside the south porch the side walls are of ashlar, with old stone benches; the two-bay roof appears to be nineteenth century, with arch-braced trusses on wooden corbels. The 


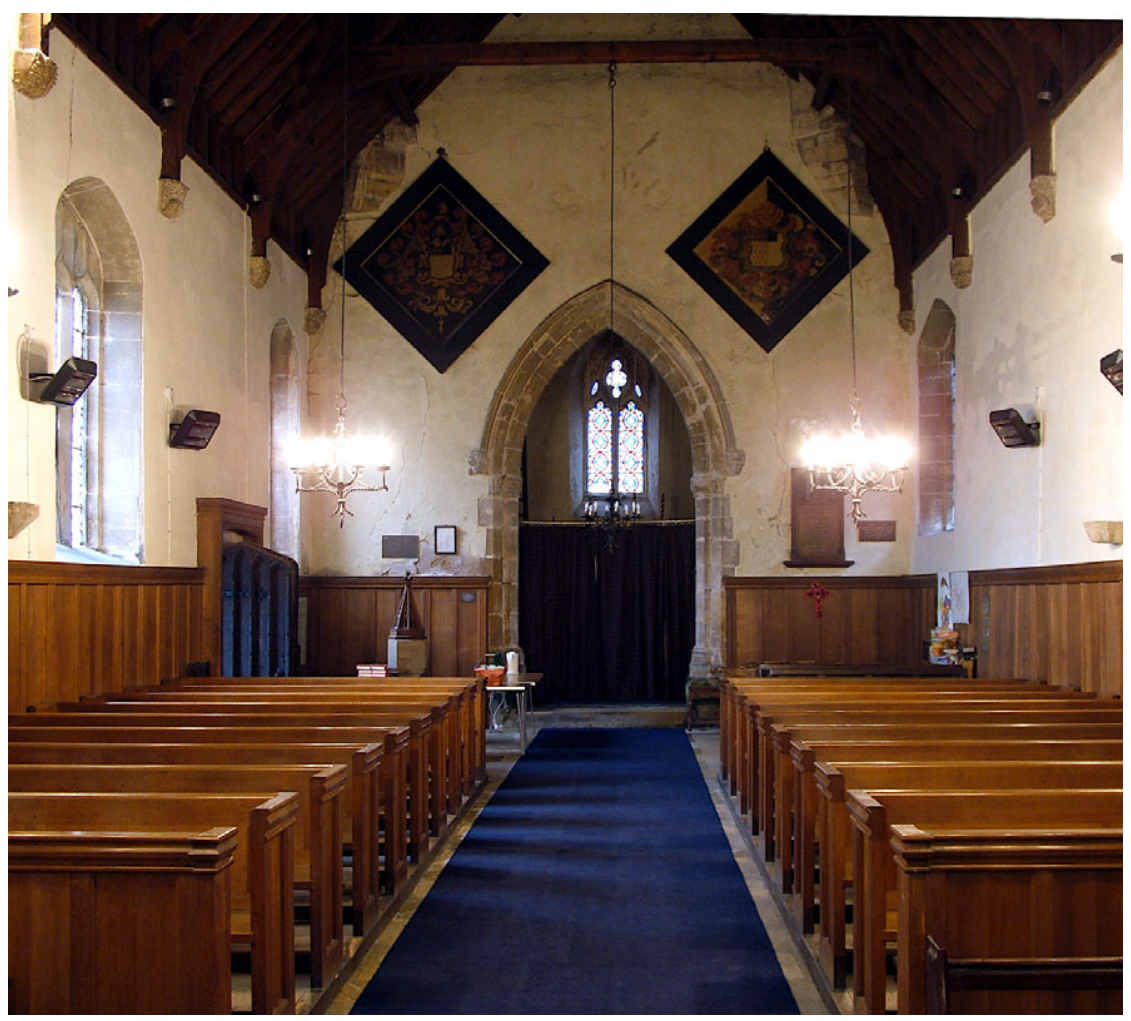

Fig 8. The interior of the church to the west showing the tower arch and west wall. Photograph: authors.

inner doorway has a Tudor arch very like the outer one, with a continuous moulding of a roll between two hollows, stopped $c 0.60 \mathrm{~m}$ above the floor. The door surround is set slightly proud of the wall, as if render was intended, and looks to have been re-cut at some restoration. Around the doorway is some infill, with the 'ghost' of an earlier round arch visible in the rubble above.

\section{THE INTERIOR FABRIC}

\section{Nave and chancel}

The interior of the main body of the church is plastered and limewashed, above a panelled dado of 1890 , except for the exposed dressings of architectural features. Below the present coating of limewash above the south doorway and on the north wall opposite is evidence of nineteenth-century painted wall texts. The south doorway has a Tudor rear arch which, like the external openings, looks to have been re-cut. Five of the windows have vaguely four-centred rear arches - the sixth, that at the west end of the north wall, has a triangular rear arch. At the west end the opening into the tower has a steep two-centred arch of two broad chamfered orders (fig 8). The date appears to be of the fourteenth century and the arch does not sit comfortably within the space as a piece of original construction and has 
the appearance of being inserted. High in the western angles of the nave are corbelled projections carrying the bases of the diagonally-set buttresses at the eastern angles of the tower. The west wall of the nave, above the tower arch, visually appears largely uniform limewash except for a faint band of lettering, probably of nineteenth-century origin, immediately around the apex of the arch. However, remote sensing imagery has revealed evidence of foliate wall painting, lying below the limewash at a higher level, that stylistically dates from the thirteenth century. ${ }^{17}$ In addition, a double roundel feature occurs at the same level in line with the apex of the tower arch. At a higher level still, roughly equating to the position where the tower angle buttresses terminate, is a large horizontal unconformity, perhaps relating to a former roof level, a construction feature such as large horizontal timber or in some way related to the blocked doorway in this wall (see below). Above the horizontal feature, the character of the plasterwork changes markedly to a much rougher finish, terminating in the apex of the present roof.

There is now no chancel arch, nor evidence that one ever existed, though it is highly likely this was the case; the side walls now simply step in and a late medieval timber screen forms the only division. The roofs of both nave and chancel belong to the restoration of 1865 .

\section{West tower}

Within the base of the tower the west window has a plain two-centred rear arch, plastered over, and on the south are two putlog holes, $c \mathrm{I} .5 \mathrm{~m}$ above the floor, open for almost the full thickness of the wall. Until 2013 access to the upper levels was via a ladder in the south-east corner. This has now been replaced by a steep timber stair rising alongside the west and then the north wall to give access to the first floor, where the walls are clear of modern plaster and the east wall has features of archaeological importance crucial to the interpretation of the church.

In the first-floor chamber, 6.Im above present ground floor level (fig 9), set slightly north of centre in the east wall is a blocked opening $0.60 \mathrm{~m}$ wide and $c \mathrm{I} .60 \mathrm{~m}$ high (the base is partially obscured by the modern floor); it has a roughly-arched head with rubble voussoirs, but the centre of the arch has gone (fig I0). A blocking of loose brick was removed from the upper part of the arch in July 2018 in order to effect a safe repair and this revealed early render on the soffit of the arch matching that on the exposed interior east wall; the render is slightly orange in colour. In February 2020 more brick and rubble was removed to effect further repairs and to examine the eastern arch on the nave side of the wall (fig II). Only $0.29 \mathrm{~m}$ of the uppermost part of the east face of the doorway was exposed as below this sits a large, flat stone forming a blocking to the nave side of the opening, and remote sensing has revealed medieval wall painting below the limewash covering to this stone extending well to each side and below; however, there was no evidence of painting at the height of the door head. The east face of the arch comprises similar rubble stone voussoirs to the west face, but the presence of some brick indicates later attempts at repair. The brick is all hand-made and probably pre-dates the nineteenth century.

The walling around the west face of the opening (ie within the present tower) is covered by the same orange render, which clearly extended beyond the line of the internal face of

I7. Brooke I986. 


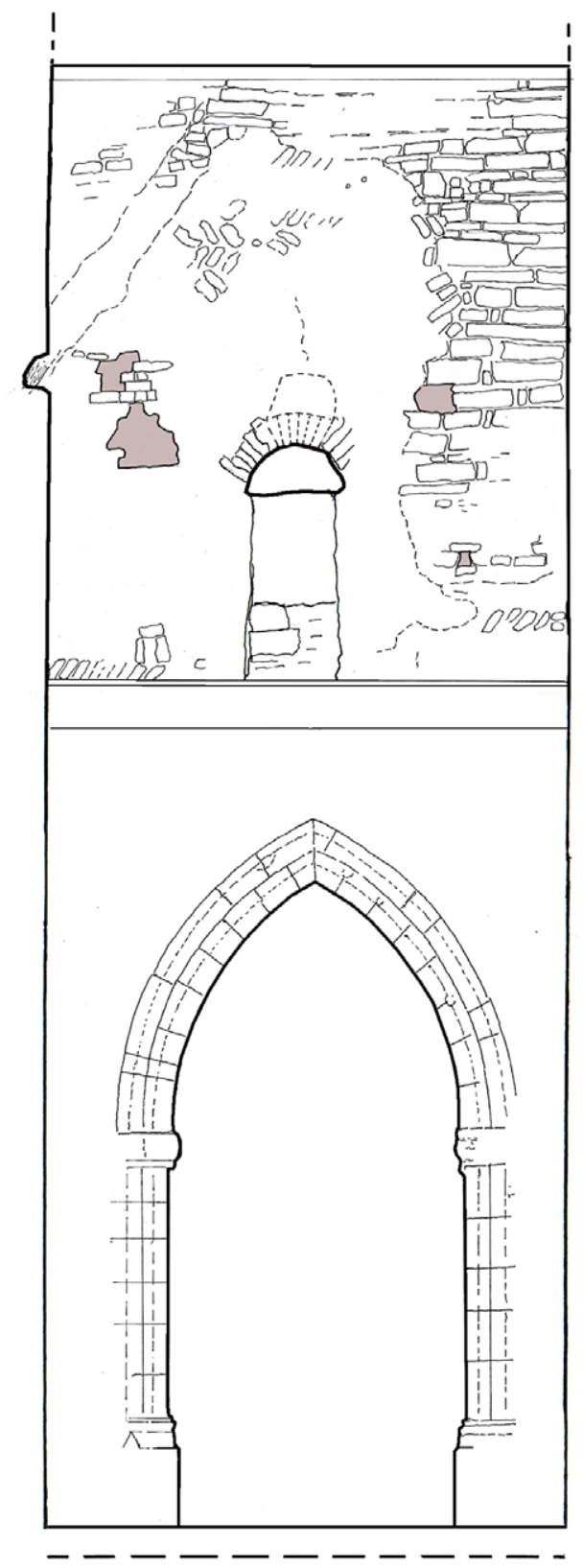

0

PFR 2020

Fig 9. Elevation drawing from the west showing the ground- and first-floor chambers of the tower. Drawing: authors. 


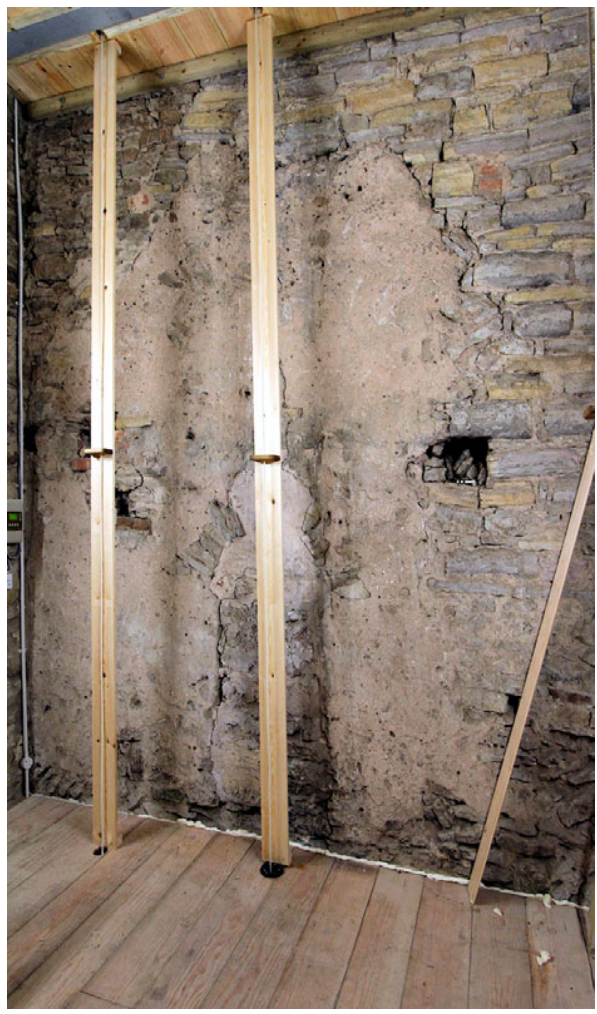

Fig Io. The first-floor chamber of the west tower looking towards the east wall. The blocked, rubbleheaded opening is visible in the centre surrounded by light orange mortar. Above, the former pitched roofline is clearly visible, partially interrupted by later alterations. Photograph: authors.

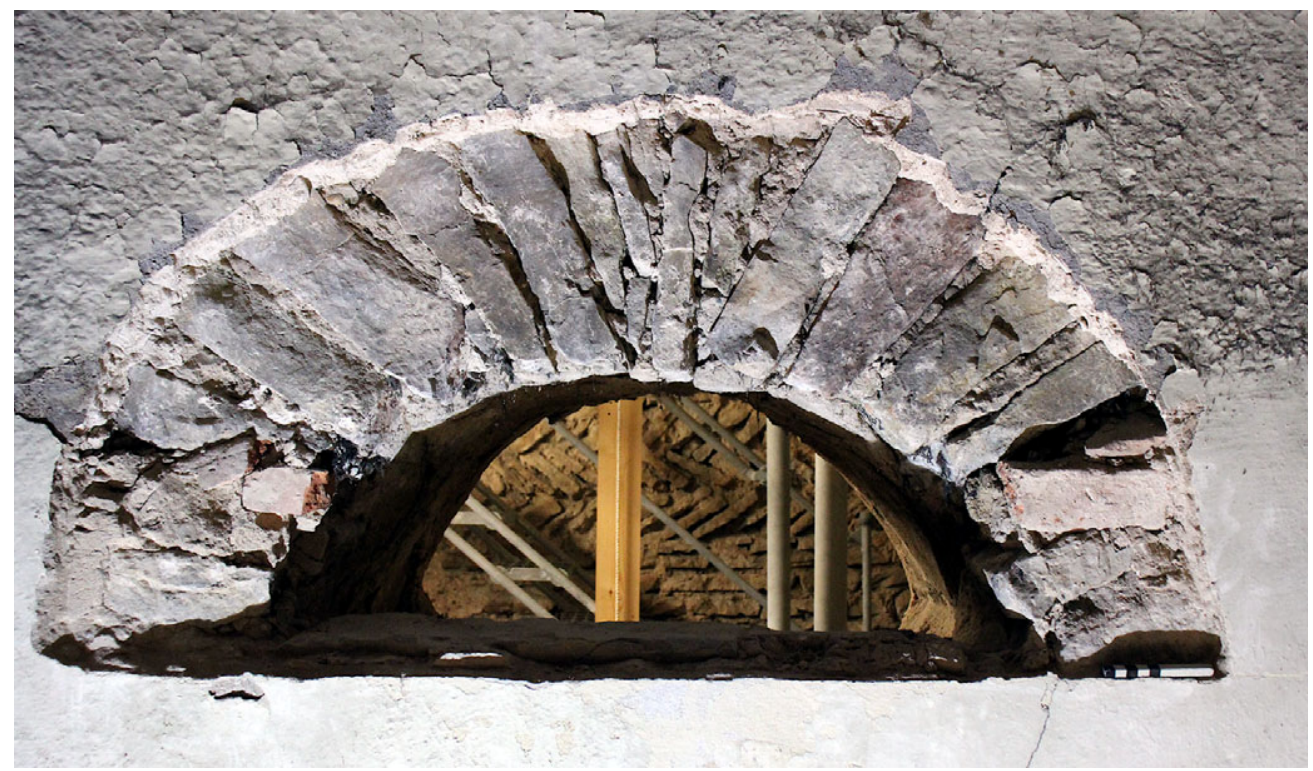

Fig II. The east face of the blocked, rubble-headed opening. Photograph: authors. 
the present north wall. On the south of the east elevation, whilst mainly ending in a ragged vertical line around a metre short of the south wall, the render does extend in a very patchy manner to this wall. This must relate to the rebuilding of this corner of the tower evident externally; the fabric beyond is coursed blue/yellow lias blocks, but the sporadic occurrence of the render on the central south wall implies it is of the same phase as the east wall. In places, courses of counter-pitched rubble show through the render, and there are several cavities in the wall face, a small putlog hole low down on the north and larger more ragged holes higher up on both sides; there are two larger holes on the north, the upper with some relatively recent brick in its surround that relate to the former position of a nineteenthcentury intermediate floor, housing the clock mechanism, that was removed in 2013. At the north-east corner, around 2.om above the floor, a previous roof line is clearly visible, pitched and rising to around the level of the present ceiling (although its apex is cut off by the later blue/yellow lias fabric), then returning again on the south (fig I2).

A small cavity in the extreme north of the east wall exposes part of an in situ rafter relating to this roof, now sealed by later masonry above. The oak timber remnant lies precisely on the angle of the former pitched roofline, leaving no doubt that it was a rafter sitting on the top of the north slope of a gable wall. A small core was removed from the timber for dendrochronological dating but proved to have an insufficient number of rings. The core was then sent for radiocarbon dating, which has yielded a corrected radiocarbon date of cal $\mathrm{AD}$ I000 \pm 33 years at 93.7 per cent probability. ${ }^{\mathrm{I} 8}$ The ${ }^{\mathrm{I} 4} \mathrm{C}$ date and calibration curve are presented in fig I3; the date is calibrated in OxCal 4.2.4 using the IntCalI3 atmospheric curve, and error is expressed at the one sigma level of confidence. The fabric above the roofline to the north is of greyer mudstone. The significance of these features is discussed in the Structural Interpretation section below.

The remaining side walls of the first-floor chamber contain a mixture of rough-coursed lias rubble of varying sizes and bands of counter-pitched rubble. Construction is, in the main, very crude, and there are numerous loose areas. In particular the west wall appears at first sight to be butted against the north and south walls, but close inspection reveals this to be just poor bonding and is in a form totally alien to later medieval building.

A modern metal stair rises to the belfry. Internally, all four walls are constructed of rough-coursed rubble blocks, mainly yellow and grey lias, with some intermittent larger limestone blocks and evidence of putlog holes, some partially filled with brick. On the east side there is clear evidence of rebuilding at the uppermost level where six courses of better quality yellow lias have been formed above the eastern belfry light commencing $1.05 \mathrm{~m}$ below the wall plate. In the lower part of the east wall, on the north side, is part of a thirteenth-century grave slab bearing an incised round-leaf bracelet cross, clearly reused from elsewhere. ${ }^{19}$ The roof comprises two diagonally positioned tie beams with raking rafters between and affixed to timber wall-plates; the date of roof is most probably I840, though the ties may be reused from an earlier phase.

\section{ANALYSIS OF THE INTERNAL RENDER AND MORTAR}

In order to further understand the nature of the orange internal render that clearly belongs to the internal face of the first-floor chamber east (below the former roofline) and part of

I8. SUERC, AMS Facility: SUERC-6I2I2 (GU38027).

I9. Brooke and Ryder forthcoming. 


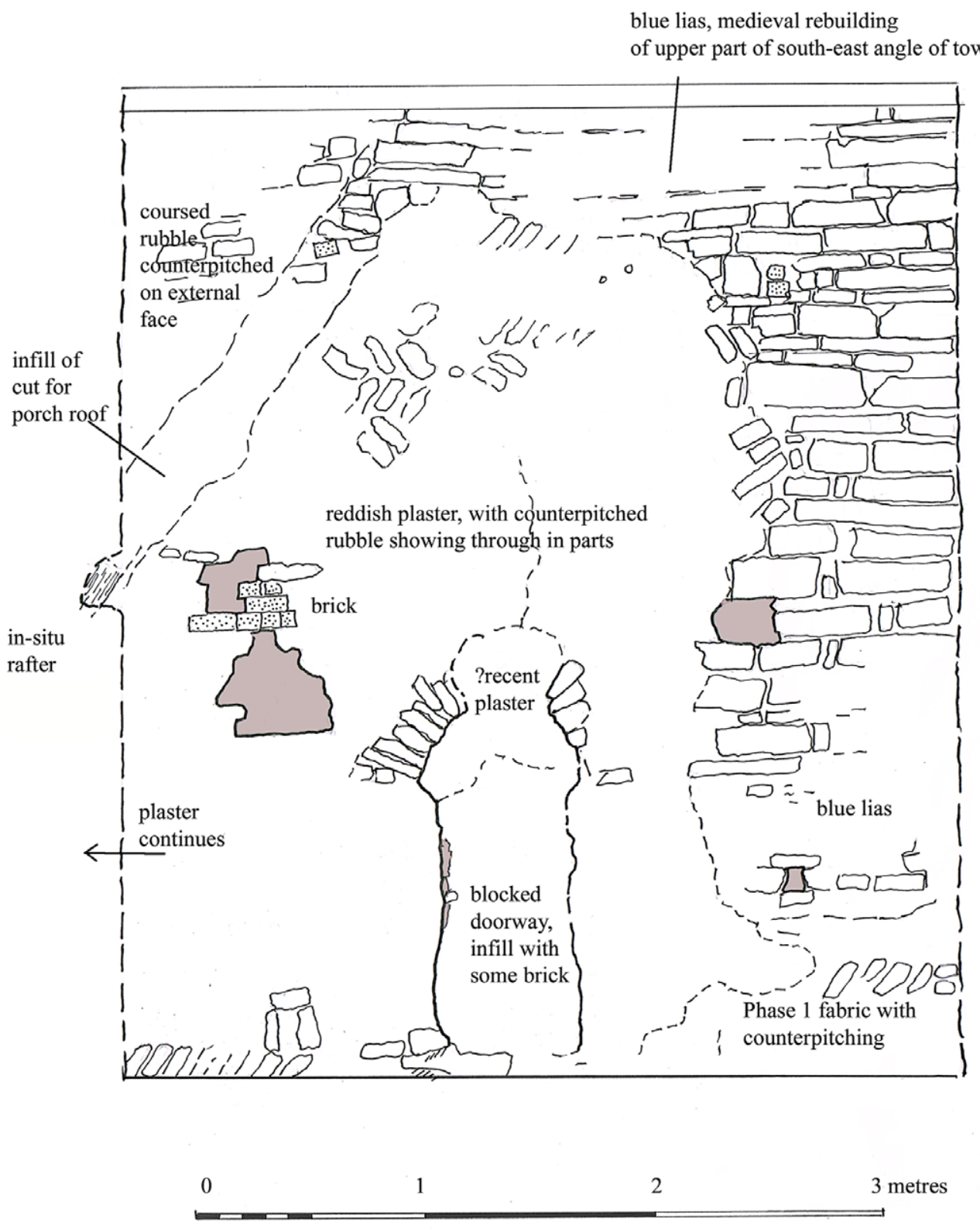

Fig I2. An interpretation of the east wall of the upper tower chamber illustrating the principal archaeological features. Drawing: authors.

the south walls, samples were extracted and examined using Raman spectroscopy at Charles University in Prague using a Thermo Nicolet 6700 FTIR spectrometer equipped with a Nexus FT Raman module (I064nm Nd: YVO4 laser excitation).

The results show that carbon is unusually present (in the form of organically-derived material such as soot or charcoal) throughout, and dispersed in the samples. This is not normally seen in the analysis of medieval mortar or render samples and it implies a 


\section{Calibration Plot}

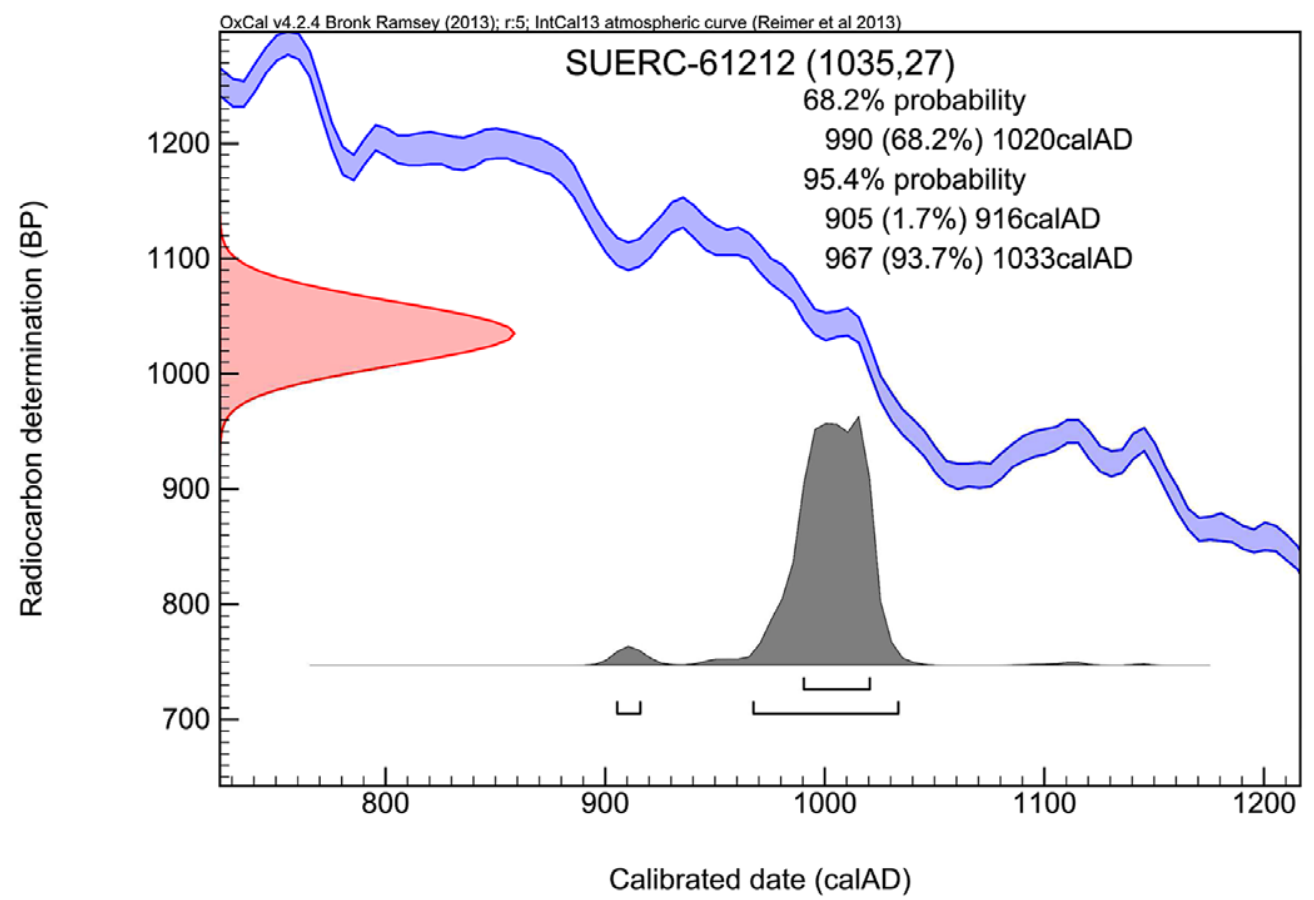

Fig 13. Radiocarbon calibration plot of the rafter sample from the east wall of the first-floor tower chamber. Drawing: SUERC.

different method of manufacture from that seen in later periods. The minerals goethite, lepidocrocite and possibly some maghemite are present, as is quartz, the latter would come from fine river sand used in the preparation of the render. This is the mixture (aside from carbon) that would be expected of a Romanesque or pre-Romanesque render-plaster with no gypsum present, the core structure being all lime putty, still only partially cured. The orange colour derives from the presence of several oxides of iron, which is noticeably almost absent in the control samples taken from mortar joints in the south and west walls. ${ }^{20}$

\section{STRUCTURAL INTERPRETATION}

It has long been known that Averham is one of the earliest surviving parish churches in Nottinghamshire, on account of its counter-pitched (traditionally 'herringbone') fabric. This was often seen as evidence of Saxon work, although more recent opinion has swung towards its more commonly being used in early post-Conquest building. ${ }^{2 \mathrm{I}}$ Counter-pitched fabric occurs in the nave, chancel and tower at Averham, although the recent investigation has shown that it represents more than one phase of building activity.

20. Brooke et al forthcoming

2I. Stocker and Everson 2006, I7; Rodwell 20I2a, I4I; Hill and Gardiner 2018, I70. 
Evidence visible inside the tower shows that the present tower replaces an earlier and lower structure, probably of two storeys, with an east-west gabled roof. Surviving internal render indicates that this structure was slightly wider than the present tower, at least to the north, and that its upper chamber had a narrow opening, either a doorway or window, probably giving into the body of the church. The providential survival of a partial rafter from the original roof has enabled a radiocarbon dating of $\mathrm{AD} 1000 \pm 33$ years, showing that at least the west wall of the nave is indubitably a pre-Conquest structure - it is possible that the Anglo-Saxon fabric is considerably older than this, and the rafter was a replacement, representing the last phase of roofing. The form and nature of the orange render implies it is an internal finish and it is confined to the area below the former pitched roof and appears sporadically on the south interior wall; this argues that the east and south walls are substantially coeval. It would appear likely that the walls of the nave and western part of the chancel - all of which have almost exclusively counter-pitched fabric - are of one phase, probably later in the eleventh century, and that the western tower, which only has occasional courses of counter-pitching, replaced an earlier structure, perhaps in the mid-eleventh century.

Unfortunately, later medieval works have resulted in the replacement of virtually all early architectural features in the church, with the exception of the high-level opening in the tower, and traces of a round-arched south doorway. The chancel would appear to have been extended in the first half of the fourteenth century, retaining three windows, a priest's door and a piscina from this period. Evidence in the fabric suggests that the upper part of the tower was remodelled as well, with an embattled parapet at about the level of the springing of the heads of the present belfry openings. The chancel arch may have been removed in the later fourteenth or fifteenth century, to judge from the date of the rood screen, which probably replaced it.

The church underwent further remodelling at the hands of the Sutton family in the early sixteenth century, dated by the arms and their initials on the new south porch. The tower, which may have been suffering from structural problems, was altered again, with angle buttresses being added and the belfry remodelled and heightened. The nave received new buttresses and new windows as well - that at the west end of the north wall may survive from a slightly earlier period.

Various post-medieval changes and restoration work are well documented. ${ }^{22}$ The Sutton Mausoleum on the north of the chancel was probably added in the later eighteenth century, and in 1858 the church was re-pewed and the interior remodelled at a cost of f600. Fig I4 shows a broad phase plan of the church based on the evidence presented here.

\section{DISCUSSION}

The west tower at Averham St Michael undoubtedly had an earlier form, potentially as a two-storied western annexe with a terminus ante quem of $c$ I033, demonstrated by ${ }^{\mathrm{I}} \mathrm{C}$ dating of what has to be the stub of an in situ rafter on the north slope of the former pitched porch roof, now sealed by later masonry. This is a rare example of a firm, scientifically validated date for pre-Conquest church fabric. The rafter may represent the original, and only, roof of the porch or may simply be the final phase of re-roofing an earlier stone structure. The

22. Southwell and Nottingham Church History Project, entry for Averham St Michael and All Angels: http://southwellchurches.nottingham.ac.uk/averham/hintro.php (accessed 2I Oct 202I). 


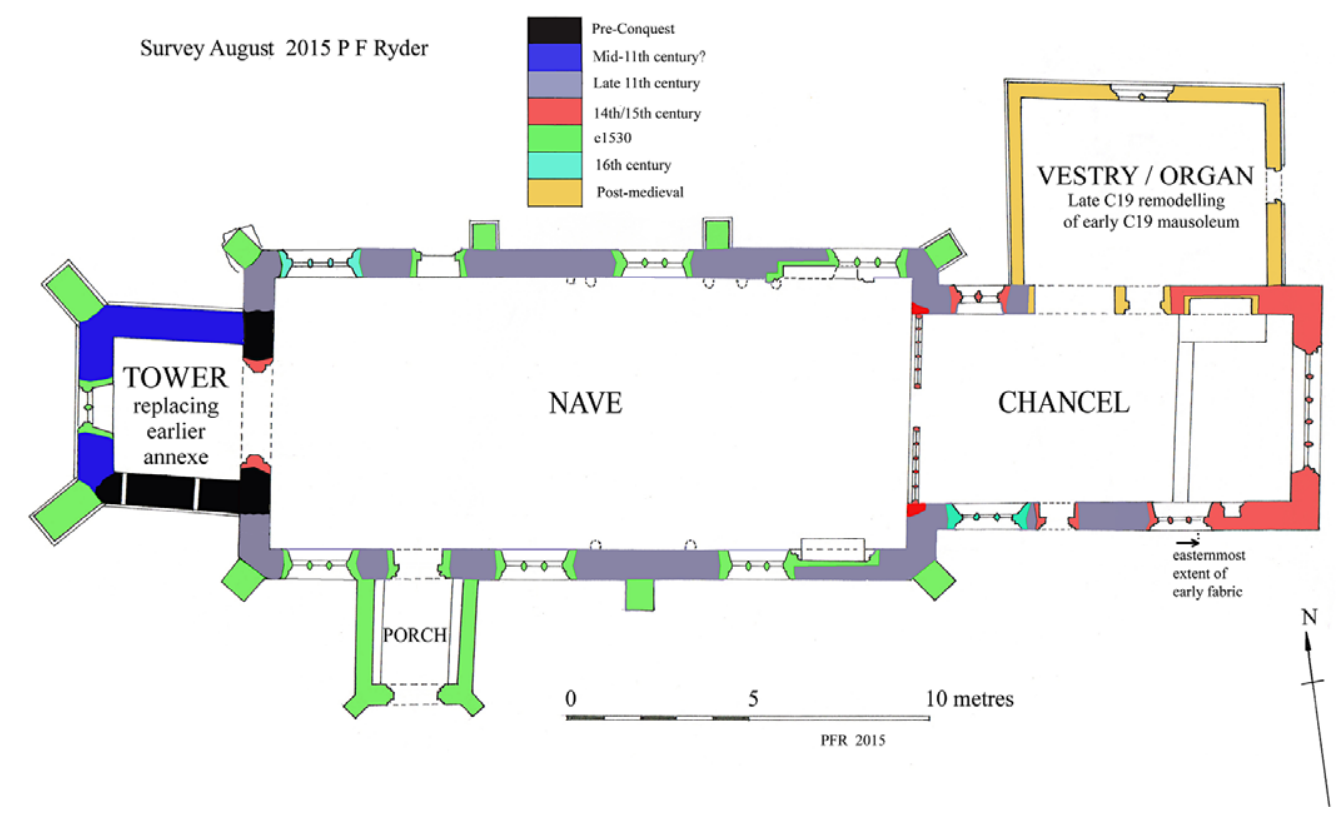

Fig I4. Phase plan of Averham St Michael giving the broad phases of fabric construction as evidenced by this survey. Drawing: authors.

extreme paucity of surviving Anglo-Saxon roof timbers, as demonstrated by Rodwell, highlights the importance of this find. ${ }^{23}$

The nature of the western structure at Averham is unclear (fig I5). The occurrence of two-storied western church porches in Anglo-Saxon architecture in the UK is rare. Those at Bardsey, Bedford St Peter, Brixworth, Deerhurst St Mary and Monkwearmouth are the best studied and cited examples, ${ }^{24}$ although the western structure at Brixworth is now thought to be more complex than a simple two-storey porch and is unlikely to be analogous to Averham. ${ }^{25}$

Although the occurrence of tower-naves is now known to be more widespread, ${ }^{26}$ there is no direct evidence that this was the case here. However, the fact that the west and the visible parts of the north walls of the tower appear to differ in form from the south and east strongly implies later rebuilding, as does the evident extension of the east wall beyond the internal face of the north; this phase may have extended to encompass the whole of the present nave and western parts of the chancel. Without excavation to the west of the present tower, to determine if buried archaeological evidence of further buildings is extant (and this area is on private land so not currently feasible), there is presently no evidence to suppose that the church was ever any larger in extent than it is today. The raising of the west end to a tower, almost certainly in the eleventh century, conforms to a general pattern seen in eastern England whereby local churches became important, visual landscape features in their own right. ${ }^{27}$

23. Rodwell 20I2b.

24. Taylor and Taylor 1965, I, and I978, 764; Hare 2009; Gittos 2013, I94-200.

25. Parsons and Sutherland 2013, I73-9.

26. Blair 2018, 403-4; Shapland 2019, 3.

27. Morris $201 \mathrm{I}, \mathrm{I} 78$. 
(a)
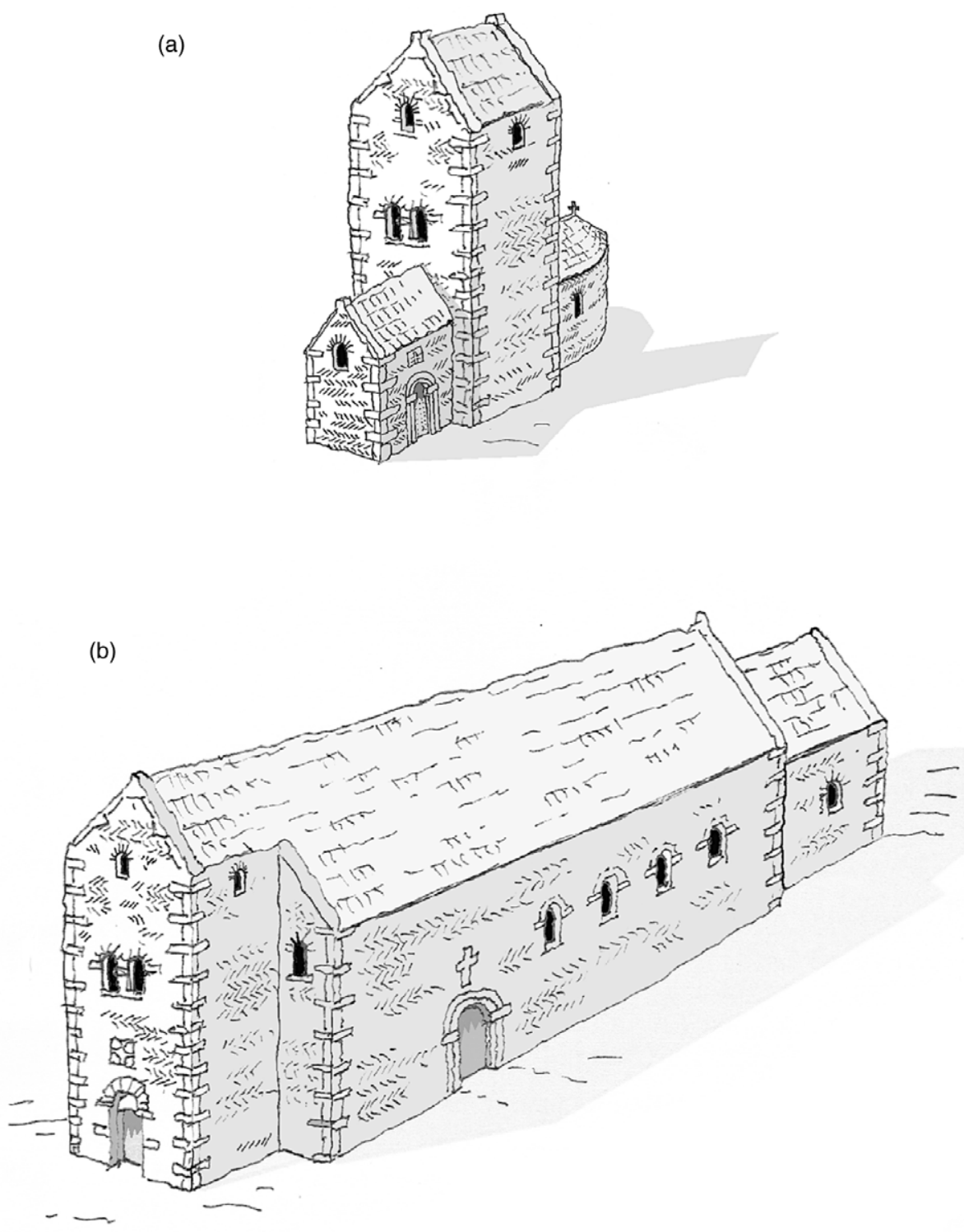

Fig 15. Conjectural reconstruction drawings of Phase I: (a) as a central tower-nave with small chancel and western chamber; (b) with a two-storey western porch, similar nave to the present and small chancel. Note: the chancels could be either square or apsidal, no evidence survives to confirm. Drawing: authors.

The most perplexing problem at Averham is that the rafter on the internal roofline in the first-floor chamber is unlikely to represent the end of a roof meeting a taller structure, such as would be the case if the structure was a western porch. However, the occurrence of rafters buried within masonry walls is not unknown, ${ }^{28}$ and therefore this remains, although

28. Courtenay and Alcock 2015, I34. 
extremely rare, a possibility. The tower-nave hypothesis appears more likely, with the surviving rafter timber at Averham representing the eastern terminus of the tower-nave roof with a slightly lower chancel abutting; the upper doorway would then open into the roof space of this chancel. It is of interest that the height of the cill to the upper doorway is almost exactly the same height above the floor $(c 6 \mathrm{~m})$ as the cill of the high-level doorway into the roof space of the western annexe at Barton-on-Humber. ${ }^{29}$ A third possibility is that there was an internal gable with a roof over spanning it, but there are no other examples of this known. A west chamber is known at Breamore, Hampshire, but this no longer extant and only the east wall now stands to gable height forming the west end wall of the nave, though now much rebuilt. It has been argued that this lost chamber was not simply an enclosed porticus but rather an antechamber, with its west wall pierced by the principal entrance to the church, and this is closely paralleled at South Elmham, Norfolk. ${ }^{30}$

No dating evidence has been found for the eastern blocked doorway in the first-floor tower chamber, but its characteristics - rubble quoins and arched rubble voussoirs are typical of Anglo-Saxon construction. Although no visible signs for a floor or gallery on the nave side of the doorway are apparent, the present tower arch is probably of the fourteenth century and has in all likelihood replaced an earlier opening, which may have removed any archaeological features relating to the area below the doorway. Alternatively, the opening may have served the function of allowing a priest to see into the nave or to the high altar if the possibility of the upper space having been utilised as a chapel is considered. ${ }^{3}$

Apart from the features in the east wall of the upper tower chamber, which define the top room of a pitched, timber-roofed structure with a sandy orange mortar finish for the interior and a rubble-headed doorway leading eastward into the nave, there are no other anomalies in the interior or exterior walls that indicate previous form and function. The conclusion is - especially given there is no return roofline on the west wall - that rebuilding and modification has taken place to form the present tower after the structure ceased to be used as a western annexe. However, the characteristics of the west and north wall masonry, and in particular the lack of proper internal bonding at the angles, indicate pre-Norman style construction, or at most late eleventh century. It seems likely, therefore, that the western annexe was converted to a tower at some point in the mid to late eleventh-century overlap period and that the remaining timber rafter of the previously pitched roof represents the only phase of roofing or the last phase of re-roofing to a structure that in all likelihood dates from the late tenth century or perhaps earlier. The following sequence is proposed:

Phase I, $c$ IO०० or earlier tenth century: a chancel with a stone-built two-storey western annexe having a pitched roof and a high-level doorway between chancel and annexe. Alternatively, a nave and chancel, of similar width to the present, with a two-storey western annexe.

Phase 2, mid-eleventh century: the western annexe was converted to a tower and the north and west walls rebuilt in a mixture of counter-pitched and coursed rubble

29. Rodwell and Atkins 201 I, fig 258.

30. Rodwell and Rouse 1984, 315.

3I. Fernie 1983, I03. 
masonry. Any structure west of the present tower (assuming a tower-nave) was demolished.

Phase 3, $c$ IIO0-25: the church, apart from the tower, was demolished and replaced by the present nave and chancel, all in counter-pitched masonry; repairs were undertaken to the south wall of the tower at this time.

The historical implications for Averham, as a stone-built, Anglo-Saxon church, are significant. Its presence might have some connection with Southwell Minster (which lies only four miles distant) or its owners the archbishops of York. Although it is unclear when Southwell attained its high status, ${ }^{32}$ it seems probable that the minster was a significant ecclesiastical establishment at least as early as 956, when a charter by King Eadwig gave a considerable portion of land around Southwell to the archbishops of York, ${ }^{33}$ and recent analysis of burials close to the minster has established that a Christian community was present by the eighth century. ${ }^{34}$ Indeed, the boundary of the 956 charter estate lay only one mile from Averham. ${ }^{35}$ Thus, it may be hypothesised that Averham was either an ecclesiastical dependency of Southwell Minster, or alternatively it may have been entirely independent as a mother-church or a small monastic community. ${ }^{36}$

\section{ACKNOWLEDGEMENTS}

The authors wish to thank Professor Richard K Morris, FSA and Richard Halsey, FSA for their opinions when the interior tower features were still obscured and for encouraging further research, and Professor John Blair, FSA for his informative views following the opening out of the tower. We are indebted to the exhaustive help given by Martin Cooper in allowing access and in his assistance with undertaking the survey.

A grant was kindly given for the radiocarbon dating of the rafter by Nottinghamshire County Council and we warmly acknowledge the support and help given by Jason Mordan, the county conservation officer, and also Robert Howard of the Nottingham Tree-ring Dating Laboratory for extracting and examining the sample. The Raman spectroscopic analysis was generously undertaken by Professors Jan Jehlička and Howell Edwards and Dr Filip Kosek.

Dr Mike Hawkes kindly assisted with the survey, and the aerial footage was taken by Richard Carlton. Dr Richard Jones, FSA gave us his expert advice on the origin of the place-name. We also offer our due thanks to Professor David Stocker, FSA and Paul Everson, FSA for their opinions of the church fabric, to the late Dr Graham Lott, formerly of the British Geological Survey, for the analysis of stone types, and to Alison Wilson of Trent and Peak Archaeology for her assistance with the radiocarbon dating. We greatly appreciate the anonymous referees' helpful suggestions and comments.

32. Everson and Stocker $2017,182-3$.

33. Thompson I9II, I5-I6; Clay and Farrer 1965, EYC, I, 5-10.

34. Jones 2020, 3-4.

35. Lyth and Davies 1992.

36. Blair 2005, 212-20. 


\section{ABBREVIATIONS AND BIBLIOGRAPHY}

\section{Abbreviations}

BL British Library, London

ERYA East Riding of Yorkshire Archives

EYC Early Yorkshire Charters

NA Nottinghamshire Archives

PRS Pipe Roll Society

SUERC Scottish Universities Environmental Research Centre

\section{Manuscript sources}

BL, Harleian Charter, 44 E 21, Chapter of Hospitalers at Ossington, 1206

ERYA, DDGU/2/3I, Copy gift in frankalmoign, c IIOO

\section{Secondary sources}

Astle, T, Ayscough, S and Caley, J I802. Taxatio Ecclesiastica Angliae et Walliae Auctoritate P. Nicholai IV, Record Commission, London Avand, M, Janizadeh, S, Naghibi, S A, Pourghasemi, H R, Khosrobeigi Bozchaloei, S, and Blaschke, T 2019. 'A comparative assessment of Random Forest and k-Nearest Neighbor classifiers for gully erosion susceptibility mapping', Water, II(IO), 2076

Belgiu, M and Drăguţ, L 20I6. 'Random Forest in remote sensing: a review of applications and future directions', ISPRS $\mathcal{F}$ Photogram Remote Sensing, II4, 24-3I

Blair, J 2005. The Church in Anglo-Saxon Society, Oxford University Press, Oxford

Blair, J 2018. Building Anglo-Saxon England, Princeton University Press, Princeton, NJ

Breiman, L 200I. 'Random Forests', Mach Learn, 45(I), 5-32

Brooke, C I986. 'Ground-based remote sensing for the archaeological study of churches', in L A S Butler and R K Morris (eds), The Anglo-Saxon Church: papers on history, architecture and archaeology in honour of Dr H M Taylor, CBA Res Rep 60, 210-I7, Council for British Archaeology, London

Brooke, C 2018. 'Thermal imaging for the archaeological investigation of historic buildings', Remote Sens, Io(9), I40I
NA, Acc 6474 PD 208/17, 'The presentation of Rev William Manners Sutton, MA Instituted I7 Aug I852'

PRS, I9I3. Pipe Rolls, 3I Henry II, II84-5, xxxiv

Brooke, C and Clutterbuck, B 2019. 'Mapping heterogeneous buried archaeological features using multisensor data from unmanned aerial vehicles', Remote Sens, I2(I), 4I

Brooke, $\mathrm{C}$ and Ryder, $\mathrm{P}$ forthcoming. A Corpus of Medieval Cross Slab Grave Covers in Nottinghamshire, Archaeopress

Brooke, C, Edwards, H, Jehlička, J and Kosek F forthcoming. 'A Raman spectroscopic examination of an Anglo-Saxon internal render at Averham St Michael's Church, Nottinghamshire, UK', $\mathcal{f}$ Raman Spectroscopy

Brown, W and Thompson, A H (eds) I940. The Register of William Greenfield 1306-1315, Part $V$ (CLIII), Surtees Society, Durham

Caley, J and Hunter, J I825. Valor Ecclesiasticus I8IO-34, Vol V, Record Commission, London

Clay, C T and Farrer, Sir W (eds) I965. 'Early Yorkshire charters: the Tison fee', Yorkshire Archaeol Soc Extra Ser, X, 47-8, no. I5

Courtenay, L and Alcock, N 2015. 'Romanesque roofs: the nave of Jumièges Abbey and the common-tiebeam tradition in northern Europe', Med Archaeol, 59(I), I22-67

Everson, P and Stocker, D 2015. Corpus of Anglo-Saxon Stone Sculpture. Volume I2: 
Nottinghamshire, Oxford University Press, Oxford

Everson, P and Stocker, D 20I7. 'Archaeology and archiepiscopal reform: greater churches in York diocese in the IIth century', in D M Hadley and C Dyer (eds), The Archaeology of the IIth Century, I77-202, Routledge, London

Fernie, E 1983. The Architecture of the Anglo-Saxons, Batsford, London

Fornaser, A, De Cecco, M, Bosetti, P, Mizumoto, $\mathrm{T}$ and Yasumoto, $\mathrm{K} 2019$. 'Sigma-z Random Forest, classification and confidence', Meas Sci Technol, 3o(2), 025002

Gittos, H 2013. Liturgy, Architecture, and Sacred Places in Anglo-Saxon England, Oxford University Press, Oxford

Hare, M 2009. 'The 9th-century west porch of St Mary's Church, Deerhurst, Gloucestershire: form and function', Med Archaeol, 53(I), 35-93

Hill, $\mathrm{N}$ and Gardiner, $\mathrm{M}$ 2018. 'The English medieval first-floor hall. Part I: Scolland's Hall, Richmond, North Yorkshire', Archaeol F, I75(I), I57-83

Jones, M 2020. 'St Mary's, Southwell, and the archbishops of York, $c$ I IOO-I 540', Northern Hist, 57(I), 3-I9

Konukoglu, E and Glocker, B 2020. 'Random forests in medical image computing', in $\mathrm{S} K$ Zhou, $\mathrm{D}$ Rueckert and G Fichtinger (eds), Handbook of Medical Image Computing and Computer Assisted Intervention, 457-80, Elsevier, London

Larking, L B 1857 . The Knights Hospitallers in England: being the report of Prior Philip de Thame to the Grand Master Elyan de Villanova for $A D$ 1338, The Camden Society, London

Lyth, P and Davies, G 1992. 'The Southwell Charter of AD 956: a new appraisal of the boundaries', Trans Thoroton Soc Notts, 96, I25-9

Mellors, R 1924. Men of Nottingham and Nottinghamshire, 2nd edn, J \& H Bell, Nottingham

Mills, A D 20Ir. A Dictionary of British PlaceNames, Ist edn rev, Oxford University Press, Oxford
Morris, J and Parker, C (eds) 1977. Domesday Book: a survey of the counties of England Liber de Wintonia. 28: Nottinghamshire, Phillimore, Chichester

Morris, R 20II. 'Local churches in the AngloSaxon countryside', in H Hamerow, D A Hinton and S Crawford (eds), The Oxford Handbook of Anglo-Saxon Archaeology, I72-97, Oxford University Press, Oxford

Parsons, D and Sutherland, D S 2013. The Anglo-Saxon Church of All Saints, Brixworth, Northamptonshire: Survey, Excavation and Analysis, 1972-20I0, Oxbow Books, Oxford

Raine, J (ed) 1872. The Register, or Rolls of Walter Gray Lord Archbishop of York (LVI), Surtees Society, Durham

Rodwell, W 20I2a. The Archaeology of Churches, Amberley, Stroud

Rodwell, W 20I2b. 'Appearances can be deceptive: building and decorating Anglo-Saxon churches', F Brit Archaeol Ass I65(I), 22-60

Rodwell, W and Atkins, C 20II. Barton-uponHumber, Lincolnshire: a parish church and its community, Vol I, Oxbow Books, Oxford

Rodwell, W and Rouse, E C i984. 'The AngloSaxon rood and other features in the south porch of St Mary's Church, Breamore, Hampshire', Antiq F, 64(2), 298-325

Shapland, M G 2019. Anglo-Saxon Towers of Lordship, Oxford University Press, Oxford

Stocker, D and Everson, P 2006. Summoning St Michael: early Romanesque towers in Lincolnshire, Oxbow Books, Oxford

Taylor, H M and Taylor J 1965. Anglo-Saxon Architecture, 2 vols, Cambridge University Press, Cambridge

Taylor, H M and Taylor J 1978. Anglo-Saxon Architecture: vol 3, Cambridge University Press, Cambridge

Thompson, A H igir. 'The Cathedral Church of the Blessed Virgin Mary, Southwell', Trans Thoroton Soc Notts, II, I5-62

Thoroton, $\mathrm{R}$ I790-6. The Antiquities of Nottinghamshire, 1677 (ed J Throsby, reprinted 1972), 3 vols, EP Publishing, Wakefield

Williams, A (ed) 2003. Domesday Book: a complete translation, Penguin Books, London 